\title{
Challenges In Teaching And Learning Efl At Karakalpak Schools (On The Example Of Nukus Public Schools)
}

\author{
Gulzira Kdirbaeva, PhD, Associated Professor, Department of Distant Teaching, Nukus State Pedaogical \\ Institute, Uzbekistan, Karakalpakstan, Nukus, kdirbaevagulzira@gmail.com \\ Venera Usenova, MA student, Department of English language and literature, Nukus State Pedaogical \\ Institute, Uzbekistan, Karakalpakstan, Nukus
}

\begin{abstract}
This article fundamentally centered on distinguishing the issues of instructing and learning English within the open schools of Nukus, Karakalpastan. The information required for the ponder were extricated from the standardized surveys given to 200 arbitrarily chosen students from the open schools of Nukus and their English instructors constituting the two bunches of members in this consider. The disobedient utilized to assemble the information were two closed surveys, one for the students and the other one for the teachers. The questions included within the surveys secured a few major issues on the portion of the understudies, instructors, course readings, educating strategies, and the tests. To analyze the information and indicate the issues, the chi-square test was connected. The test was performed to see in the event that the contrasts among the extents of the members who chose diverse reactions to the same questions were critical. Through the factual examination of the comes about, various issues with respect to the instructors, the learners, the reading material and the strategies were uncovered, such as: instructors don't utilize educating helps amid instructing, school libraries are not well prepared to be of benefit for the learners of English, classrooms are destitute in terms of offices and physical conditions, the instructors don't educate in English, the English reading material are not appropriate for the students' level of capability, and the Service of Open Instruction did not honor the hard-working instructors some time recently, but nearly from 2000th instructors are energized by Service. Still in our school we have issue in different things and to evacuate the issues to the degree conceivable, a few proposals were given.
\end{abstract}

Keywords: Nukus, public schools, Karakalpakstan, problems of teaching and learning English.

Received: 07.12.2020 $\quad$ Accepted: 12.01.2021 $\quad$ Published: 02.02.2021

\section{INTRODUCTION}

Language instructing contains a long history in Karakalpakstan. It dates back to the conclusion of XIXth and the starting of the XXth centuries when the government-sponsored academic institution of learning beneath the title of Nukus Educational Established was built up in Nukus, the capital of Karakalpakstan. The outside language instructed at that time was English, German, and French. Since at that point, outside dialects have been among the components of educational programs in Nukus schools. Be that as it may, the destinations of educating and learning English have not been palatably met. As a result, nearly none of the tall school graduates are able to utilize the English dialect for the reason of communication, but for those who learn English in dialect establishing exterior schools. Such a disappointment within the instructive framework of the nation warrants examination. Besides, from 2008 Service of Higher and Secondary Education Establishments with collaboration of British Council guided "PreSETT project" (PreService English Teachers Training) in 8 teach which was coordinated to create communicative aptitudes, and the venture effectively propelled and actualized in all Higher Educational Establishments which prepare English teachers. So these organize in instructing outside languages were a spinning point in Uzbekistan, Karakalpakstan.

Changes in English language teaching venture points to realize enduring change within the measures of ELT in Uzbekistan by creating the learning encounter of Pre-Service understudies and by setting clear exit guidelines in line with universal guidelines. The modern pre-service educator preparing program created in organization with the Ministry of Higher and Secondary Special of the Republic of Uzbekistan, 17 pre-service educators preparing educate in Uzbekistan and Norwich Institute of Language Teaching will presently give all future teachers (1,700 yearly) with the abilities and encounter to reply to the developing request coming from the youthful generation.

The PRESETT Educational modules has been embraced and actualized in all the colleges capable for the preparing of English teachers since 2013. The venture exercises this year will incorporate assist scale-up of the program across the country; coach and educator preparing in key ranges of the change counting appraisal and fabric advancement; venture outside assessment; and arrangement exchange 
occasions to bring together venture partners and universal accomplices to shape the procedure for encourage upgrade of the quality culture in English educator education.

The years of independence became for Uzbekistan, on the one hand, years of transformations in all spheres of life of both the state and the entire society, years of full-scale social, political and economic reforms, and, on the other hand, years of searching for new fateful decisions in all areas of social life of society, decisions unexpected, and solutions in difficult situations, years of extraordinary approaches to various problems. One of such decisive issues for the development of national statehood and social construction was the question of the education system. On December 10, 2012, a Resolution of the President of the Republic of Uzbekistan was adopted on measures to further improve the system of teaching foreign languages", in which it was mainly about the status of the English language [1].

What motivated this research on language learning and teaching is the great value of the English language in Karakalpakstan. Of course, regarding the vast range of efforts made in relation to the trend of teaching and learning English in Karakalpakstan, one may think that its objectives have been completely achieved, but it is not true. The experiences of students and teachers and the results of various studiessome to be mentioned later, in this regard have proved that there are many problems in the area of learning and teaching English in Karakalpakstan.

The abstract nature of learning necessitates constant research in the field to find solutions to questions and difficulties language educators and program developers face. Thus, the constant change and development in language teaching methods is meant to accommodate new findings in the field.

In the last fifteen to twenty years, language teaching in Iran has seen a slow and gradual change from traditional methods, in which deductive learning was stressed and learning of a language was done mainly through teaching and studying of grammar and translation, to more modern methods based on communicative approaches. This move towards the latter methods reflects two points. First, the change in language teaching forum form traditional methods to communicative ones, and second, the recognition of changes in the kind of proficiency Karakalpak learners of foreign languages, specifically English, expect to gain, such as a more efficient oral and listening proficiency besides reading comprehension.

Despite the turn from traditional approaches of language learning and teaching, some applied linguists point out research results indicating the efficacy of some practices and techniques of these approaches which boost adolescent and adult learning in SL classroom. Students' attitudes to procedures and in general to language learning are also crucial. Research in this field of language learning has shown that learners' negative perceptions can be detrimental to the whole learning program (Green, 1993 \& Wenden, 1987).

Teachers' perception toward the efficacy of methods and practices employed in teaching a foreign language is yet another significant factor to consider in developing a program. Willingness or unwillingness to experiment with a new method or to use innovations in language teaching is very decisive. Incongruities among teachers' beliefs based on their actual experience with learners and theoretical framework of their teaching can lead to difficulties in teaching which in turn negatively affect learners (Salomon 1998). Therefore, this study was an attempt to find the reasons for the problems and then to present probable solutions to eradicate them to the extent possible.

\section{BACKGROUND}

\section{A. Teachers' Problems}

The conception of a teacher is someone with a great number of decisions to make at every moment of classroom instruction. In some cases, research findings can guide those decisions. In others, research can inform professional judgment, but decisions must be based on experience and intuition rather than knowledge. However, decisions will be aided by the survey of the English teachers' of Nukus city, where we tried to evaluate the course-book of the local schools. Moreover, the Ministry of Education tried to solve one more problem by lowering the recruitment standards for English teachers. Historical analysis of the educational system of Uzbekistan, with specific references to the number of teachers of English and the preparation of such teachers in Uzbekistan shows that the number of teachers increases. This study might contribute to a better understanding of the issues related to teacher training and provide clues that may aid in recruiting and training better teachers for the future.

While our state teaching practice we attempted to examine the extent to which guidance- and high school teachers in the urban schools of Nukus, Karakalpakstan, were involved in the practice of moonlighting. Our study particularly intended to identify the number of teachers who had additional jobs for any reason. It was also intended to find a relationship between the teachers' moonlighting and their needs. Some of the important results were as follows:

1. English teachers of Nukus were overloaded;

2. What made the teachers have a second job was to satisfy their needs; 
3. Financial problems and low social status were other reasons that made the teachers get involved in a second job.

Since 1960, due to the educational developments and national language policy, the desire for education and especially higher education has been increasing rapidly in Uzbekistan. However, the government has not been able to cope with it due to the shortage of facilities, the most important of which is the shortage of qualified teachers. Teachers of English have not been an exception in this regard.

The faculty was established in 1937 as a faculty of Russian language and literature within the pedagogical institute. It was renamed the Faculty of Foreign Languages in 1963. The faculty has a rich history and traditions. Famous scientists, academicians M.Nurmukhamedov, U.Khamidov, Honorable Writer of Uzbekistan and Karakalpakstan, Hero of Uzbekistan T.Kayipbergenov, A.Uteniyazov and a number of statesmen graduated from this faculty. When the Pedagogical Institute was reopened in 1990, the Faculty of Russian Language and Literature continued its work. It has been operating under the name of the Faculty of Russian-English Philology since 2000 and the Faculty of Foreign Languages since 2004. From 1990 to 2017, this faculty was headed by Prof. K. Koshanov, Associate Professor B. Khoshanov, Ph.D. B. Shaniyazov, Ph.D. M. Abdullaev, Associate Professor G. Kurbaniyazov, Ph.D. Mamirbaeva. In 1937, 25 students were attending day-time English classes. All subjects of this speciality followed the same curriculum carried out in the teacher training University in Moscow (Russia). In all teacher training centers, the students were required to pass 5 years in order to finish their studies. Later on, the number of credits and the courses underwent some revisions. At present, the students are required to pass 4 years course of BA and then to have Higher Education Degree 2 years MA study.

At present, in spite of the large number of universities, colleges, teacher-training centers, and all training English teachers, the problem of teacher shortage still remains.

\section{B. Textbooks Problems}

The textbooks used over the years in Karakalpakstan have passed through various changes in the light of the methods employed. To the best of our knowledge, the first structured textbook taught at the schools of Nukus was English Coursebook series (the Ministry of Education of USSR, 1954). These books were designed on the basis of the Grammar-Translation Method. They were the first government sponsored textbooks published by the Ministry of Education which were taught in public schools before Independence of Uzbekistan.

Prior to the adoption of the relevant decree, $76 \%$ of schools functioned in the republic, where English was taught as a foreign language. After the adoption of the decree, $95 \%$ of schools in the republic from the first grade introduce the study of a foreign language, - said the head of the department of general education and specialized schools of the Ministry of Public Education of the Republic of Uzbekistan Abdurahim Nasirov. In the first grade, a foreign language is studied in a playful way, without the alphabet, reading and writing, which are introduced from the second grade. In addition to the textbook for the first grade "Kid's English", 446 thousand manuals for teachers and parents in Uzbekistan have also been published and sent to all schools.

To cope with the problem of textbook the Ministry of Public Education decided to design a new series of English textbooks and a number of experts were commissioned to do the job. The end product of the six-year plan was the Fly High English series (The Ministry of Education, 2000) which have been teaching at schools for about 20 years. The Kid's English series (The Ministry of Education, 2016) was mainly designed on the basis of the principles of the Communicative Teaching Method. Kid's English series (The Ministry of Public Education, 2016) is still being used for teaching English in the schools of Uzbekistan.

Comparison of previous course with the new designed one show that suffered from the following short-comings:

-The content was quantitatively inefficient.

-The structural drills were quantitatively insufficient. In spite of the above short- comings, old course books presented the pronunciations of the words in an effective way.

We examined the effectiveness of the Fly High English textbooks taught in Uzbekistan after the Independence. These textbooks were revised to replace western-oriented contents with National materials. The researcher had attempted to examine various factors such as the English curriculum guidelines, teachers' proficiency in English, teachers' and textbook writers' perception of the goals of the English curriculum and the test items given to the students. We concluded that the revised textbooks did not develop in the learners the ability to use the language in a real situation. In his view, these textbooks were not in conformity with the normal English patterns and language use.

C. The Studies Related To Methods and Evaluation

Service of Open Instruction after displaying recharged educational modules of the Public Education Ministry attempting to show a brief account of English language educating and learning in 
Uzbekistan, specified the taking after focuses: 1. In show disdain toward the disappointment of the Grammar-Translation Approach, it is still utilized at the schools.

2. Language structure rules are clarified to the understudies in subtle elements, but they are not anticipated to utilize them in real-life circumstances i.e., the utilization is the center of the consideration, but the use of the rules isn't emphasized.

3. Since language structure constituted the bulk of the tests, instructors had linguistic use.

The specified issues were for the most part ascribed to the improper strategy utilized by the teachers of English. Among the issues which we highlighted most of the understudies had uncommon note pads for composing down the Mother Tongue implications of the English words in. This off-base propensity was empowered by teachers. In expansion, the understudies interpreted the English words utilizing Mother Tongue orthography. As a result, they may not learn the right elocution of the words.

\section{STATEMENT OF THE PROBLEM}

It is presently nearly common information that formal teaching of English at schools in Nukus has fizzled to attain most of its targets. The English classes of schools don't make inspiration in understudies and rarely stimulate their intrigued. Hence, one can claim that the destinations of educating and learning English have not indeed been approximated, and there are many problems in this area in Nukus. What should be done to realize positive comes about in instructing a remote dialect? In our supposition, it is vital to conduct classes utilizing different strategies - conventional and non-traditional, based on the subject of the lesson, and to guarantee the taking after conditions:

1) The level of information and the capacity to ace the language of the bunch understudies are examined and on this premise they are given assignments;

2) Participation by understudies of classes is guaranteed and none of the understudies is cleared out out of the consideration of the instructor;

3) Within the classroom, talk basically within the remote dialect being considered. Boundless words can't be instantly interpreted, but clarified with the assistance of motions and facial expressions in other words;

4) The bunch is partitioned into micro-groups, strategies of trade of judgments, suppositions, comments are utilized;

5) An opportunity is made for the free trade of students' conclusions; botches are rectified by joint investigation and settled by cases;

6) Different linguistic, lexical, topical and other diversions are organized; the parts are allotted based on the level of information of the understudies;

7) Within the classroom, strategies of working with pictures (composing a story, questions, working with circumstances), recordings (seeing and talk), news (understanding, propagation) are utilized. This consider is an endeavor to offer a few rules in understanding a few of the existing problems in this regard, conjointly looks for answers to the taking after questions:

IV. RESEARCH QUESTIONS

1. Do the financial, social, and person status of the English instructors impact their instructing (from the points of view of Karakalpak school L2 learners and instructors)?

2. Do the financial, familial, and mental status of the L2 learners influence their learning English (from the points of view of Nukus school L2 learners and instructors)?

3. Is there a need of reasonable, steady, and productive strategy utilized by the Nukus school English teachers?

4. Are irregularity with the students' level of capability in English, and unseemly introduction of the materials the most insufficiencies of the Nukus school English textbooks?

\section{METHOD}

\section{A. Participants}

This consider was conducted with two bunches of members. The primary bunch of members comprised of 120 male and female school learners. All the members were arbitrarily chosen out of twenty schools from all five districts within the city of Nukus. Out of twenty schools chosen, ten were female and the other ten were male schools. These understudies were ninth, tenth, and eleventh grades at school with diverse English capability level. The moment gather of members comprised of 20 male and female English teachers from the same schools. Their ages extended from 25 to 45, and they all speakers of Karakalpak, Uzbek and Russian.

\section{B. Materials}

In this think about, the instrumented of information collection comprised of two distinctive surveys. The primary one was the students' survey containing 43 questions, each speaking to a variable. The moment 
one was the teachers' survey with 51 things. To get the surveys, the analyst initially utilized the rebellious which were utilized in comparative investigate over 15 a long time back with the exemptions of making discernible sum of changes and alterations by the analyst. With the assistance studying of hypothetical and viable materials the things of the surveys changed from yes/no to a Lickert scale in which there are five answers to a question. At that point the numbers of the things of each survey expanded from 15 to 51 and 15 to 43 for the instructors and the understudies separately. These changes and alterations made the unused surveys to have more than twenty unused categories which brought about in unused factors and subsequently unused regions of concerns that have not been utilized some time recently. As said over, after a few alterations and changes of the things and organize of the surveys, two surveys, one for the instructors and one for the understudies, based on Lickert scale were affirmed by the board of specialists to be utilized. In this think about, the legitimacy of the surveys was moreover decided by the board of specialists. The unwavering quality of the surveys was indicated to be 0.75 , utilizing Cronbach Alpha through a pilot ponder with twenty haphazardly chosen tall school understudies and five English instructors at the tall schools from which the understudies were chosen.

\section{Procedures}

The pilot think about was carried out on twenty school boys and girls (ten boys and ten girls) who were haphazardly chosen from four schools (school 12, 37, 21, and 5), and after that the ponder was performed on five English teachers from the same schools. After the pilot consider was completed, it was looked into and two alterations were made on the surveys: to begin with, the things which had more than one variable were re-written independently on the surveys with as it were one variable-this brought about for the numbers of things to be expanded, moment, all the things of both surveys were adjusted and inserted in a DATA ANALYSIS like survey rather than a standard sheet of paper with things composed on them. After that, the surveys based on Lickert scale were affirmed to be utilized on the genuine consider with 200 understudies (100 boys and 100 girls) from all five districts within the city of Nukus city, and 30 teachers (15 males and 15 females) from the same schools.

The real think about was performed utilizing the modern and affirmed surveys based on the Lickert scale. Due to the limitations and restrictions it took three days to total all the surveys. All ambiguities by the understudies were reacted by the analyst at the time of replying the surveys. After completing all the surveys by the understudies and the instructors, the crude information were prepared to be factually analyzed.

\section{DATA ANALYSIS}

Once the inquire about information have been collected with the help of diverse sorts of information collection methods, the following stage of the investigate was to analyze those information. The objective of this portion is three overlay: to begin with detailing the rates of the students' and the teachers' reactions given to the things of the questions; moment, deciding in the event that the rates gotten are critical or not; and third, deciding in the event that the reactions given to the things of the questions show any issues concerning instructing and learning English as an outside language.

The students' survey contained 43 questions each speaking to a variable. It is worth saying that among the 43 factors fair 17 showed up to be risky. The issues and comes about are as takes after:

- Education of the Student's Father: $24.6 \%$ of the students' fathers have auxiliary level education, $4.5 \%$ uneducated, and $49.7 \%$ of the students' fathers have high education, $15.6 \%$ have relate degrees and fair 5.5\% of the fathers have B.A and over degrees. $\mathrm{P}=0<0.05$ Basic esteem $=9.49$ O.V. $=136.8 \%$ D.F. $=4$;

- Education of the Students' Mother: $33.2 \%$ of the students' mothers' have auxiliary high education, $46.2 \%$ have completed the auxiliary education, and $13.6 \%$ have related degrees. As it were $20.5 \%$ of them have finished B.A and over degrees. In other words, most of the students' mothers don't have high education. $\mathrm{P}=0<0.05$ C.V $=9.49$ O.V. $=144.09 \%$ D.F. $=4$;

- Sources for Learning English: $46.2 \%$ of the students utilize school classes as the as it were source for learning English, and 48.5\% of the students don't utilize the English organizing as well as the tall school classes for learning English. $\mathrm{P}=0<0.05$ Basic esteem=7.81 O.V.= 57.16 (T4.3), 71.55(T4.4) D.F.= 3 ;

- Whether a pre-test has been given or not: $77 \%$ of the students expressed that their teachers had not given them pre-tests at the starting of the school year. $\mathrm{P}=0<0.05$ basic esteem $=9.49$ O.V.=156.9 D.F.= 4 ;

- Teachers' Creativity: $33.5 \%$ of the teachers appear a few inventiveness in their educating method. $\mathrm{P}=0<0.05$ Basic esteem $=9.49$ 0.V. $=29.9$ D.F. $=4$;

- Rapport with students and English teachers: $35.4 \%$ of the teachers have fulfilling inviting connection with students. $\mathrm{P}=0<0.05 \mathrm{C} . \mathrm{V}=9.49 \mathrm{O} . \mathrm{V}=58.6 \mathrm{D} . \mathrm{F}=4$; 
- Using Instructive helps by the English teachers: $64.3 \%$ of the understudies claimed that their English teachers don't utilize any instructive helps. $\mathrm{P}=0<0.05$ Basic esteem $=9.49$ O.V. $=254.79$ D.F. $=4$;

- Problems of the English Reading material: $89.5 \%$ of the students claim that their English text books are being bulky. O.V. $=604.6$ D.F. $=4 . \mathrm{P}=0<0.05$ Basic esteem $=9.49$;

- Short comings of the English Reading material: $93 \%$ of the students accept that their English reading material clarify a restricted number of the modern words. D.F. $4 \mathrm{P}=0<0.05$ Basic esteem $=9.49$ O.V.=316.12;

- Short comings of the English Reading material: $84.5 \%$ of them accept that their English reading materials don't have sufficient bore works out. $=0<0.05$ Basic esteem $=9.49$ 0.V.-316.12 D.F. $=4$ P;

- Short comings of the English reading part of the lesson: $83.4 \%$ of the students demonstrated that their English reading material don't contain a clear understanding of linguistic items. $\mathrm{P}=0<0.05$ Basic esteem $=9.49$ O.V. $=316.12$ D.F. $=4$;

- Short comings of the English reading part of the lesson: 77\% believe that in their English readings part there's not any specify of lyrics and/or comics. $\mathrm{P}=0<0.05$ Basic esteem $=9.49$ D.F. $=4$ O.V.= 316.12 ;

- Short comings of the English readings: $80 \%$ of the students pointed out that in their English reading material the works out are not in suitable places. $\mathrm{P}=0<0.05 \mathrm{C} . \mathrm{V}=9.49$ O.V.=316.12 D.F $=4$;

- The Number of students in a course: $42 \%$ of the understudies shown that their classes contain more than 40 students. $\mathrm{P}=0<0.05$ Basic esteem $=7.81$ O.V.=174.73 D.F. $=3$;

- Whether a library is accessible as school: $87 \%$ of the students demonstrated that they are incapable to utilize the sources at their school library to memorize English. $\mathrm{P}=0<0.05, \mathrm{C} . \mathrm{V}=9.49$, O.V. $=567.25$, D.F. $=4$;

- The students' parents' month to month wage: $42.3 \%$ of the students' family salary is between 200,000 and 500,000. $\mathrm{P}=0<0.05$ Basic esteem $=9.49$ Entireties. O.V. $=110.68$ D.F. $=433 \%$ of their pay is between 500,000 and 1,000,000. SUMs.

The teachers' survey comprises of 51 questions each speaking to a variable. Just like the students' reactions, a Chi-square (x2) test was run for each variable as well as an examination of change. The factors whose gotten $\mathrm{x} 2$ values (P values over), are not significant or in spite of being noteworthy don't demonstrate any issues are not talked about here. The strategy in this area is the same as that of the past one; that's, in arrange to indicate the issues of educating and learning English from the teachers' focuses of see, each of the over factors are put into the shape of a invalid speculation (Ho). At that point the comes about of the Chi-square test run for each variable are displayed in an analysis and concurring to the comes about, issues are recognized. It is worth specifying here that among these 51 factors fair 33 were demonstrated as issues which are as follows:

Comes about of Instructors Fulfillment with teachers' work: $60 \%$ of the teachers are not substance with their employments at the Public of Education;

Comes about moving forward the tuning in expertise through different channels: $100 \%$ of the teachers attempt to make strides their tuning in aptitude through a few of the specified channels;

Comes about rapport with teachers and students: $70 \%$ of the instructors have inviting relationship with their students;

Comes about the aptitudes for the most part emphasized by the English teachers: the abilities generally emphasized by the English teachers are: talking $80 \%$, and perusing $60 \% .80 \%$ of the English teachers demonstrated their contradictions to put accentuation on tuning in and writing;

Comes about of the impact of utilizing diverse instructing strategies by distinctive instructors on the students' learning: $60 \%$ of teachers expressed that utilizing diverse educating strategies contains a negative impact on the students' learning;

Comes about whether the irregularity in utilizing British and American English variants by teachers: $75 \%$ of the English instructors accept that the irregularity in utilizing British and American English by diverse instructors is problematic;

Comes about whether as it were the English reading material: $60 \%$ of the English instructors tend to utilize other sources in instructing though as it were $40 \%$ of the English teachers as it were utilize the English course readings in classes;

Comes about whether a pre-test: $60 \%$ of the English teachers don't allow a pre-test to their students;

Comes about of the allotment of a few time to illuminate the students' issues in learning English: $45 \%$ of the teachers distribute no time to fathom the students' issues related to their learning English;

Comes about whether the teachers' manual is accessible or not: $70 \%$ of the teachers claimed that the teachers' manual isn't available; 
Comes about whether the teachers' manual will be valuable: $70 \%$ of the English teachers concur that the teachers' manual will be useful;

Comes about whether the need of presence of teachers' manual: 70\% of the English teachers demonstrated that the need of presence of teachers' manual will have negative impact on educating procedure;

Comes about Lesson plans: $70 \%$ of the English teachers utilize lesson plans;

Comes about utilizing the students' mother tongue in lesson: $90 \%$ of the English teachers utilize Uzbek, Karakalpak to an incredible degree (more than two thirds);

Comes about of the need of having work: $95 \%$ of the teachers expressed that the compensation of the teachers isn't adequate which they require part time job;

Comes about the require for a bunch of English teachers to fathom the teachers' issues in instructing: 85\% of the English instructors expressed that they feel a require for a gather of specialists on English to unravel their issues in teaching;

Comes about the Impact of the Students' family offer assistance to unravel their issues with English: $90 \%$ of the English teachers stated that the students' family offer assistance incorporates a positive impact on the learning of the students;

Comes about of the suitability of 1st review of direction school for beginning the learning of English: $95 \%$ of the teachers accept that to begin with review of direction school isn't fitting for beginning the learning of English;

Comes about of utilizing the students' mother tongue in course: $90 \%$ of the English teachers utilize Uzbek, Karakalpak and Russian to an extraordinary degree (more than two thirds);

Comes about of school or some time recently will be the suitable time to begin learning of English: $100 \%$ of the English teachers shown that the suitable time to begin learning English will be the basic school or before;

Comes about of the impacts of students' financial status on their learning of English: 50\% of teachers accept that there's a coordinate relationship between the students' financial status and their learning of English. In other words, those who have distant better; a much better; a higher; a stronger; an improved" >a distant better money related status may learn the English dialect superior than those who have a destitute financial status;

Comes about Reviewing of the English textbooks' materials from simple to difficult: $40 \%$ of the teachers shown that the materials within the English course readings don't continue from simple to troublesome. That's, the students may come over more troublesome materials some time recently the less demanding ones;

Comes about of utilizing the students' mother tongue in course: $90 \%$ of the English teachers utilize Uzbek or Karakalpak (Russian) to an awesome degree (more than two thirds);

Comes about of whether the drills of English reading material are displayed in a mechanical, important, and communicative arrange: $90 \%$ of the English teachers accept that the drills of English course readings are not displayed in a mechanical, important, and communicative order;

Comes about of Lack in getting the interpretations of the unused words: $40 \%$ of the English teachers demonstrated that there's an insufficiency in getting the interpretations of the modern words in English textbooks;

Comes about of whether the English reading parts of the lesson are of great quality in terms of outlines, pictures, colors, etc.: $85 \%$ of the teachers of English accept that the English course readings don't appreciate great quality in terms of outlines, pictures, and colors;

Comes about of the accessibility of instructive helps at schools: $75 \%$ of the English teachers expressed that theinstructive helps are not accessible at the schools they are teaching;

Comes about of Regulating verbal examinations in schools: 90\% of the English teachers claim that it isn't conceivable to manage verbal examinations with respect to school offices and circumstance (such as space, audio-visual helps, etc.), in spite of the reality that the students are required to pass an verbal examination as one of their school subjects;

Comes about of Components causing issues in doing verbal drills and regulating verbal examinations: an incredible larger part of the teachers accept that all the four sorts of factors-shortage of time (90\%), need of offices (100\%), larger than usual classes $(75 \%)$, and not sufficient understudies or teachers' interface (85\%), cause issues in doing verbal drills and regulating verbal examinations;

Comes about of the quality of classrooms in terms of estimate, light ,color, etc.: $65 \%$ of the instructors announced that the classrooms in which they are instructing are not of a great quality in terms of measure, light, color, etc.; 
Comes about of the normal number of understudies in classes: $90 \%$ of the teachers demonstrated that their English classes contain of more than 30 understudies, which could be an exceptionally high number for a language class;

Comes about of thought of the students' person contrasts by the instructive framework: All the English teachers concurred on the truth that "the instructive framework does not consider the person contrasts among the students in terms of their levels of language proficiency". In other words, the students with distinctive levels of language capability are considering in same lesson and are instructed the same materials.

Comes about of the plausibility of doing verbal drills: Most of the English teachers have confessed that they don'tpay any consideration to verbal drills;

Comes about of Adequacy of the teachers' compensation: none of the English teachers accept within the adequacy of their salary;

Comes about of whether the instructive frameworks: distinctive values to diverse educating qualities. None of the English teachers accept that instructive framework pays consideration to distinctive instructing qualities;

Comes about of whether the English course readings are fitting for the students' mental capacities: $95 \%$ of the instructors accept that the English course readings have not been planned in similarity with the students' level of mental abilities;

Comes of the realness of the English readings: $95 \%$ of the English teachers accept that materials within the English reading material are not authentic;

Comes about of the adequacy of the English class time: All English teachers communicated that the English course time isn't adequate at all;

Comes about of whether the English tests: similarity with the objectives of educating English set by the service of instruction Lion's share of the teachers concurred that the English tests are not in congruity with the objectives of educating English set by the service of educations;

Comes about of the adequacy of the English course time: all English teachers communicated that the English lesson time isn't adequate at all;

\section{DISCUSSION}

\section{Some of Problems Specified from the Students' Responses and the Effects of them on Each Other}

One may claim that there's no self-evident connection between the parents' instruction and the students' English learning since there are numerous understudies with great command of English whose fathers or mothers don't have college degrees. But, in the event that one considers the awesome impact of the students' fathers' and mothers' instruction on a few other factors as "the significance given by the family to the students' learning of English", "the family's offer assistance in tackling the students' problems" and the students' deliberate to proceed their ponders at university", one can come to this result that the students' parents' education plays an awesome part within the instructive status of the students. Fathers and mothers with college degrees give their children with reasonable economic, cultural, and mental foundation which is of extraordinary significance within the instructive advance of the students from childhood to adulthood.

With respect to the deficiently pay of the students' guardians, There's no ought to clarify the reasons why one's financial status may impact his/her learning of each department of sciences particularly an outside language. By and large talking, the alluring financial status may give the students with way better and more viable get to the schools, way better teachers, way better and more sources for learning. But, in this think about consideration is paid to the relationship between the financial status of the understudies and their get to the diverse sources for learning English. As the comes about demonstrate, the inadequately pay of the students' guardians can impact the students' get to distinctive sources for learning English. In other words, the students with way better financial status appreciate more sources for learning English. For case, concurring to the information given by the students, for almost three fourth of the understudies whose parents' wage is less than 200,000 Entireties a month, school classes serve as the as it were source for learning English, but an awesome larger part of the students with alluring financial status appreciate extra sources as language organizing, tapes, movies and books.

The teachers' need of imagination is another issue which was indicated from the students' reactions. This issue may influence other perspectives of the instructing technique. For occasion, as the information examination demonstrates, utilizing instructive helps is beneath the impact of the teachers' inventiveness. In other words, the more imaginative instructors utilize more instructive helps. Of course, this truth cannot be considered freely of other issues. Maybe inadequately offices at schools, inadequately 
course time and the teachers' disappointment with their occupations within the Public Education lead to the teachers' need of imagination, and small utilize of instructive helps as well.

Expansive number of understudies in each lesson certainly is another issue. Over-crowding ruins compelling learning and successful instructing since the existing restricted openings counting instructive helps, classroom estimate and teachers' consideration have to be separated among a huge number of students. In other words, students don't have satisfactory presentation to English. The impact of this issue - the expansive number of students in a course - on two other issues bolsters the above-mentioned explanations. One of the specified issues is that no pre-test is given to the students at the starting of the school year, as talked about prior. The moment issue whose relationship with the expansive number of the students in a lesson was found as noteworthy is "doing verbal drills". Clearly a second/foreign dialect requests an extraordinary bargain of verbal drills on the portion of teachers and the learners. Learners of a modern language will not learn to utilize the language smoothly just by perusing and composing. Teachers ought to grant their students satisfactory openings to hone tuning in and talking. One successful implies for practicing can be verbal drills. Be that as it may, the expansive number of students in each course limits the students' openings to do verbal drills since hone requests adequate time and vitality, which stands against the over-crowded classes and so on.

B. Some Problems Specified from the Teachers' Responses and the Effects of them on Each Other

Teachers' disappointment with their employments may be primarily due to the inadequately compensation, and / or due to this truth that the instructive framework does not grant distinctive values to the diverse educating qualities. In other words, as the information appears instructors accept that for the existing instructive framework an experienced and well-skilled teacher is rise to with a destitute educator. The reason anything is, this issue - the teachers' disappointment with their work - may profoundly influence the technique of educating on the portion of teachers and thus language learning on the portion of learners, as well. The impact of this issue on the need of inviting relationship between teachers and their students, and distributing a few time for tackling the students' issues with learning English are the illustrations which loan themselves well to bolster the significance of teachers' disappointment with their work.

The lacks of English readings such as English reading material drills are not displayed in a mechanical, important and after that communicative arrange; their materials are not evaluated from simple to troublesome; the reading material are not of great quality in terms of outlines, pictures, and colors; they are not appropriately planned for the mental capacities of students; and at last, English reading partsof the lesson are not bona fide.

\section{SOLUTIONS}

It is coherent that there's an arrangement for each issue, and the said issues are not exemptions. In this portion, the analyst tries to put forward a few arrangements ideally to kill the issues of educating and learning English within the Nukus public schools. A few of these arrangements are proposed to the Ministry of Education, a few to the instructors, and the others to reading material journalists.

A. A few Recommendations to the Ministry of Education

- The schools ought to be well prepared with legitimate instructive helps.

- The schools ought to be given with libraries containing valuable and curiously English books.

- The physical conditions of the classrooms ought to be progressed in terms of light, color, estimate.

- The normal number of understudies in a course ought to be brought down so that the understudies can appreciate the existing openings to an alluring degree.

- The time designated to instructing English ought to be expanded.

- The schools ought to be given with a few offices which can streamline the organization of verbal examinations.

- A bunch of specialists is required within the Ministry of Education for fathoming the issues instructors confront in instructing and assessment.

- The instructors ought to be provided with Teachers' Manuals.

- The teachers' compensation ought to be expanded to fathom their monetary issues and to fulfill their needs.

- And at long last, the Ministry of Education ought to provide distinctive values to distinctive educating qualities to encourage the instructors to extend the quality of their educating.

B. A few Recommendations to the Teachers

- Teachers ought to know that utilizing instructive helps can encourage the method of educating and learning English.

- It has been demonstrated that giving pre-tests makes the instructors to be commonplace with the levels of the students' capability at the starting of the school year. 
- Clearly, it is way better for the instructors to utilize the Teachers' Manuals and lesson plans.

Instructing books other than the course readings can spur the understudies to memorize English way better and more successfully.

- Teachers ought to be steady in utilizing British or American English articulation.

- It is way better for the instructors to create inviting connections with the understudies so that the students feel at ease within the lesson and subsequently learn the lessons more successfully.

- Instructors ought to emphasize all the four aptitudes - listening, talking, perusing and composing- to reach at an alluring status.

- The instructors ought to create their tuning in aptitude through different channels such as the English talking radios, tv, etc.

C. A few Recommendations to the Textbook-Writers

- Textbook-writers ought to pay more consideration to the quality of the books in terms of outlines, pictures, colors,

- The English reading material ought to be suitable for the mental capacities of the understudies etc.

- The materials included within the English reading material ought to be reviewed from simple to troublesome.

- The reading material drills ought to be reviewed from mechanical to significant to communicative.

- The English content books endure from a few major issues and inadequacies, as the need of relationship among the diverse materials, need of clarification of modern words, need of curiously materials as brief stories, lyrics, melodies, and jokes, and need of genuineness. The course reading journalists ought to take all the above-mentioned focuses into thought and expel the issues to the degree conceivable.

\section{CONCLUSION}

This investigate was essentially carried out to find the existing issues in instructing and learning English as a outside dialect within the tall schools of Nukus, Uzbekistan, Karakalpakstan. The ponder appeared that the English instructors alluded to 33 issues and the understudies to 17. All the issues and their impacts on each other were examined and illustrated in points of interest within the going before areas. Among the over students' issues, there are a few which can influence a few other ones; they are as takes after:

- The students' fathers' instruction influences the significance given to the learning of English by the family, the students' family offer assistance fathoming the students' issues in learning English, and the students' purposeful to proceed their ponders at university;

- The students' mothers' instruction influences the significance given to the learning of English by the family, and the students' purposeful to proceed their considers at university;

- The teachers' inventiveness influences the utilize of instructive helps by the teachers;

- The students' family salary influences the students' get to distinctive source of learning English;

The issues found from the teachers' reactions are 33, among the issues there are a few which can influence other ones, they are as follows:

- Teachers' fulfillment with their employments within the Service of Instruction influences the teachers' neighborly relationship with their understudies, and their deliberate to designate a few time for understanding the students' issues in learning English;

- Teachers' inviting relationship with their understudies influences their deliberate to distribute time for tackling the students' issues in learning English;

- The normal number of understudies in a lesson influences firstly the instructing of as it were the English course readings and not any other English books, besides, regulating a pre-test and thirdly doing verbal drills. Doing oral drills is also relevant to using educational aids by the teachers

\section{REFERENCES}

[1] Green, J. M. (1993). Student attitudes toward communicative and non-communicative activities: Do enjoyment and effectiveness go together? Modern Language Journal, 7, 1-10.

[2] Salomon, A. M. (1998). Communicative grammar teaching: A problem for and a message from international teaching assistants. Foreign Language annuals, 31, 552-566.

[3] Wenden, A. L. (1987). What do second-language learners know about their language learning? A second look at retrospective accounts. Applied Linguistics, 7, 187-201.

[4] Ahymadpoor, Z. (2004). Studying the Problems of EFL Teaching in High Schools. The Roshd ELT Journal, 18(71), 15-21.

[5] Carver, D. J., \& Dickinson, L. (1982). Learning to be self-directed. In G. S. E. In M. Geddes (Ed.), Individualization. London: Modern English Publications. 
[6] Nunan, D. (2003). The impact of English as a global language on educational policies and practices in the Asia-Pacific region. TESOL Quarterly, 589-613. 